\title{
GAMBARAN KUALITAS HIDUP LANSIA DENGAN HIPERTENSI DI WILAYAH KERJA PUSKESMAS RENDANG PADA PERIODE 27 FEBRUARI SAMPAI 14 MARET 2015
}

\author{
Sri Santiya Anbarasan
}

Program Studi Pendidikan Dokter Fakultas Kedokteran Universitas Udayana

\begin{abstract}
ABSTRAK
Latar Belakang: Hipertensi merupakan suatu masalah kesehatan terbesar di dunia, terutamanya di negara berkembang. Menurut data dari Dinas Kesehatan Provinsi Bali penderita hipertensi di Bali pada tahun 2010 berjumlah 8837 orang. Sedangkan jumlah kunjungan lansia yang menderita hipertensi pada tahun 2013 adalah sebanyak 1354, yaitu sebesar 9,41\% dari seluruh kasus yang berkunjung ke Puskesmas Rendang pada 2013. Permasalahan hipertensi yang tinggi terutama pada golongan lansia mempengaruhi kualitas hidup lansia.
\end{abstract}

Tujuan Penelitian: Mengetahui gambaran kualitas hidup pada lansia dengan hipertensi.

Metode Penelitian: Jenis penelitian ini deskriptif kuantitatif. Penelitian dilakukan di posyandu lansia wilayah kerja Puskesmas Rendang Kabupaten Karangasem pada periode 27 Februari sampai 14 Maret 2015. Teknik pengambilan sampel yang digunakan consecutive sampling dengan jumlah sampel 60 orang. Instrument yang digunakan berupa kuesioner, dimana kuesioner ini dibuat oleh WHO yaitu World Health Organization Quality Of Life - Bref (WHOQOL-BREF). Teknik analisis data dengan analisis univariat dan bivariat.

Hasil: Kualitas hidup lansia secara umum baik (58.3\%), kualitas kesehatan fisik lansia buruk $(71.7 \%)$, kualitas psikologis baik (61.7\%), kualitas personal sosial tidak terlalu berpengaruh $(50.0 \%)$ dan kualitas lingkungan buruk (73.3\%).

Kesimpulan: Kualitas hidup lansia secara umum baik, hanya buruk pada kualitas kesihatan fisik dan lingkungan.

Kata kunci: Hipertensi, Kualitas hidup, Lansia, World Health Organization Quality Of Life - Bref (WHOQOL-BREF)

\section{OUTLOOK ON QUALITY OF LIFE OF ELDERLY WITH HYPERTENSION IN PUSKESMAS RENDANG AREA DURING PERIOD 27 FEBRUARY TO 14 MARCH 2015}

\section{ABSTRACT}

Background: Hipertension is one of the biggest health problem faced in the world, especially in developing countries. According to data from Bali Province Health Service, patients suffering from hipertension in Bali in 2010 accounts to 8837 people. Whereas total visit of elderly with hypertension in 2013 sums up to 1354, which is 9,41\% from total cases that visited Puskesmas Rendang in 2013. High number of hypertension cases especially in elderly affects their quality of life.

Aim: To know the quality of life of elderly suffering from hypertension.

Method: The type of study is descriptive quantitative. Study was conducted in elderly posyandu in Puskesmas Rendang, Karangasem district during period of 27 February till 14 March 2015. Sample was obtained through consecutive sampling technique with a total sample of 60 people. Instrument used in the form of questionnaire which was created by WHO that is World Health Organization Quality Of Life - Bref (WHOQOL-BREF). Data analysis technique used was univariate analysis and bivariate analysis.

Result: Quality of life of elderly is generally good (58.3\%), physical health quality of elderly is bad (71.7\%), psychological quality is good (61.7\%), personal social quality is not too influential $(50.0 \%)$, and environment quality is bad $(73.3 \%)$. 
Conclusion: Quality of life in elderly with hypertension is generally good, only physical health quality and environment quality is bad.

Keywords: Hypertension, Quality of life, Elderly, World Health Organization Quality Of Life - Bref (WHOQOL-BREF)

\section{PENDAHULUAN}

\section{A. Latar Belakang Masalah}

Hipertensi termasuk salah satu masalah kesehatan terbesar di dunia, terutamanya di negara berkembang. Hipertensi adalah suatu keadaan dimana terjadi peningkatan tekanan darah sistolik $\geq 140 \mathrm{~mm}$ $\mathrm{Hg}$ atau tekanan darah diastolik $\geq 90 \mathrm{~mm} \mathrm{Hg}$ sesuai dengan kriteria The Seventh Report of The Joint National Committee on Prevention, Detection, Evaluation, and Treatment of High Blood Pressure (JNC 7). ${ }^{1,6}$ Angka proportional mortality rate akibat hipertensi di seluruh dunia mencapai $13 \%$ atau 8 juta kematian setiap tahunnya. ${ }^{2,4}$ World Health Organization (WHO) mencatat bahwa 65,74\% penderita hipertensi berada di negara berkembang, termasuk di Indonesia. ${ }^{4,5,7}$ Angka kejadian hipertensi di Indonesia menunjukkan di daerah pedesaan masih banyak penderita yang belum terjangkau oleh pelayanan kesehatan. Menurut data dari Dinas Kesehatan Provinsi Bali penderita hipertensi di Bali pada tahun 2010 berjumlah 8837 orang. Pada tahun 2011 provinsi Bali memiliki jumlah penduduk mencapai 1,5 juta jiwa dan memiliki lansia yang tidak kalah banyak yaitu mencapai angka sekitar 300 ribu jiwa. 3

Puskesmas Rendang di Kabupaten Karangasem menunjukan data bahwa hipertensi juga menjadi masalah kesehatan utama dimana penyakit hipertensi berada di urutan ketiga dari sepuluh penyakit terbesar pada tahun 2013. Jumlah kunjungan lansia yang menderita hipertensi pada tahun 2013 adalah sebanyak 1354, yaitu sebesar 9,41\% dari seluruh kasus yang berkunjung ke Puskesmas Rendang pada 2013. Pada tahun 2015 jumlah kunjungan dari bulan Januari hingga bulan Februari mencapai 188 kunjungan. Hal ini menunjukkan peningkatan jumlah yang menderita hipertensi, dimana sebagian besar diderita oleh lansia. Gejala menuanya struktur penduduk (aging population) yang terjadi di Indonesia kini dalam tahapan transisi demografi, epidemiologi, ekonomi, dan sosial budaya sebagai akibat keberhasilan pembangunan nasional.

Organisasi kesehatan dunia atau World Health Organization (WHO) mendefinisikan kualitas hidup sebagai "Individuals' perception of their position in life in the context of the culture and value systems in which they live and in relation to their goals, expectations, standards and concerns' (WHOQOL Group dalam Lopez and Synder, 2004). Berdasarkan definisi tersebut, maka dapat dilihat bahwa kualitas hidup tidak hanya menyangkut penilaian individu terhadap posisi mereka dalam hidup, melainkan juga adanya konteks sosial dan juga konteks lingkungan sekitar yang juga mempengaruhi kualitas hidup.

Pada penelitian yang dilakukan oleh Trevisol dkk (2011) ditemukan bahwa pada individu yang menderita hipertensi, memiliki kualitas hidup yang lebih rendah dibandingkan pada individu dengan tensi yang normal. Pada pasien dengan hipertensi namun menjalani pengobatan yang rutin juga dilaporkan memiliki kualitas hidup yang lebih tinggi dibandingkan dengan individu dengan tekanan darah tidak terkontrol dan tidak dalam pengaruh obat-obatan. Menurut Li dkk (2005) pada individu dengan hipertensi memiliki kualitas hidup yang rendah terutama pada dimensi fisik. Kualitas hidup yang buruk ini merupakan komplikasi dari hipertensi itu sendiri. Oleh karena itu untuk menurunkan angka morbiditas dan angka mortalitas, salah satunya dengan memperbaiki kualitas hidupnya.

Adanya permasalahan hipertensi yang tinggi terutama pada golongan lansia di wilayah kerja Puskesmas Rendang ini menarik pihak kami untuk membuat penelitian mengenai hipertensi. Keragaman hasil dari aspek kualitas hidup pada lansia memutuskan kami untuk meneliti mengenai gambaran kualitas hidup pada lansia hipertensi.

\section{B. Rumusan Masalah}

Bagaimana gambaran kualitas hidup pada lansia yang mengalami hipertensi di posyandu lansia wilayah kerja Puskesmas Rendang Kabupaten Karangasem pada periode 27 Februari sampai 14 Maret 2015?

\section{Tujuan}

Untuk mengetahui karakteristik lansia dan gambaran kualitas hidup pada lansia dengan hipertensi di posyandu lansia wilayah kerja Puskesmas Rendang pada periode 27 Februari sampai 14 Maret 2015.

\section{Manfaat}

Adapun manfaat yang diharapkan dapat diperoleh dari penelitian ini adalah memberikan gambaran kualitas hidup pada lansia yang menderita hipertensi dan dapat dijadikan referensi bagi pihak yang membutuhkan serta sebagai dasar untuk acuan pembuatan program kesehatan baru untuk meningkatkan kualitas hidup lansia dan meningkatkan pelayanan kesehatan, khususnya terhadap lansia yang menderita hipertensi di wilayah kerja Puskesmas Rendang. 


\section{TINJAUAN KEPUSTAKAAN}

\section{Hipertensi}

Tekanan darah adalah desakan dari dalam dinding pembuluh darah untuk menjaga agar darah tetap dapat mengalir. ${ }^{8}$ Tekanan darah dipengaruhi oleh curah jantung dan tahanan perifer. ${ }^{8}$ Hipertensi atau biasa dikenal dengan tekanan darah tinggi, dimana keadaan tekanan darah dalam keadaan istirahat terukur dengan spygmomanometer yang telah terkalibrasi ditemukan tekanan sistolik lebih dari $140 \mathrm{mmHg}$ dan atau tekanan diastolik lebih dari 90 mmHg. ${ }^{1}$ Hipertensi dibagi menjadi dua berdasarkan penyebabnya, hipertensi primer/ essential yang tidak diketahui penyebabnya dan hipertensi sekunder yang merupakan hipertensi karena penyakit sistemik lainnya. ${ }^{8}$ Hipertensi juga diklasifikasikan berdasarkan derajatnya, menurut The Seventh Report of The Joint National Committee on Prevention, Detection, Evaluation, and Treatment of High Blood Preasure (JNC 7) klasifikasi tekanan darah pada orang dewasa terbagi menjadi kelompok normal, prehypertension, stage Ihypertension, dan stage II hypertension. ${ }^{6,9}$

Hipertensi esensial adalah penyakit multifaktorial yang timbul terutama karena interaksi antara faktor- faktor risiko tertentu. Faktor- faktor risiko yang dapat mendorong timbulnya kenaikan tekanan darah tersebut adalah faktor risiko seperti diet dan asupan garam, stress, ras, obesitas, merokok, genetis; sistem saraf simpatis; tonus simpatis dan variasi diurnal; keseimbangan antara modulator vasodilatasi dan vasokonstriksi: endotel pembuluh darah berperan utama, tetapi remodeling dari endotel, otot polos, dan interstisium juga memberikan kontribusi akhir; pengaruh sistem otokrin setempat yang berperan pada sistem rennin, angiotensin dan aldosteron. ${ }^{8}$ Kaplan menggambarkan beberapa faktor yang berperan dalam pengendalian tekanan darah yang mempengaruhi rumus dasar tekanan darah= curah jantung $x$ tahanan perifer.

Pada umumnya hipertensi tanpa gejala yang mencolok. Manifestasi klinis baru terlihat setelah hipertensi menahun berupa nyeri kepala saat terjaga, kadang-kadang disertai mual dan muntah, akibat tekanan darah intrakranium, penglihatan kabur akibat kerusakan retina karena hipertensi, ayunan langkah tidak mantap karena kerusakan sususan saraf, nokturia karena peningkatan aliran darah ginjal dan filtrasi glomerulus dan edema dependen akibat tekanan kapiler.Peninggian tekanan darah kadang merupakan satu- satunya gejala, terjadi komplikasi pada ginjal, mata, otak, atau jantung. Gejala lain adalah sakit kepala, epistaksis, telinga berdengung, rasa berat ditengkuk, sukar tidur, mata berkunangkunang, dan pusing.Faktor risiko hipertensi dapat dibedakan menjadi dua, yaitu faktor yang tidak dapat dimodifikasi dan faktor yang dapat dimodifikasi. Antara faktor yang tidak dapat dimodifikasi adalah umur, jenis kelamin, riwayat keluarga dan genetik. Antara faktor yang dapat dimodifikasi adalah merokok, konsumsi garam, konsumsi lemak jenuh, kebiasaan konsumsi alkohol, obesitas, olahraga dan stres. ${ }^{8}$

Diagnosis hipertensi ditegakkan melalui anamnesis, pemeriksaan fisik dan pemeriksaan penunjang. Anamnesis yang dilakukan meliputi tingkat hipertensi dan lama menderitanya, riwayat dan gejala penyakit yang berkaitan seperti penyakit jantung koroner, penyakit serebrovaskuler, dan lainnya. Riwayat penyakit dalam keluarga juga digali serta gejala yang berkaitan dengan penyakit hipertensi. Perubahan aktivitas atau kebiasaan seperti merokok, konsumsi makanan, psikososial keluarga, pekerjaan, dan lain- lain dapat ditelaah lebih lanjut, guna mendapat informasi terkait. Dalam pemeriksaan fisik dilakukan pengukuran tekanan darah dua kali atau lebih dengan jarak dua menit, kemudian diperiksa ulang dengan kontralateral. Pengukuran di kamar periksa dilakukan pada posisi duduk di kursi setelah pasien istirahat selama 5 menit, kaki di lantai dan lengan pada posisi setinggi jantung. Ukuran dan peletakan manset (panjang 12-13 cm, lebar $35 \mathrm{~cm}$ untuk ukuran dewasa) dan stetoskop harus benar (gunakan suara Korotkoff fase I dan V untuk penentuan sistolik dan diastolik). ${ }^{8}$ Menurut Arief Mansjoer, dkk., pemeriksaan penunjang meliputi pemeriksaan laboratorium rutin yang dilakukan sebelum memulai terapi bertujuan menentukan adanya kerusakan organ dan faktor risiko lain atau mencari penyebab hipertensi. Pada umumnya, pemeriksaan urinalisa, darah perifer lengkap, kimia darah (kalium, natrium, kreatinin, gula darah puasa, kolesterol total, kolesterol HDL). Sebagai tambahan dapat dilakukan pemeriksaan lain, seperti klirens kreatinin, protein urin 24 jam, asam urat, kolesterol LDL, TSH, dan ekokardiografi. ${ }^{8}$

Tujuan pengobatan pasien hipertensi adalah mencapai target tekanan darah yaitu $<140 / 90 \mathrm{mmHg}$ dan untuk indivisu berisiko tinggi seperti diabetes mellitus, gagal ginjal target tekanan darah adalah $<130 / 80 \mathrm{mmHg}$. Tujuan lain adalah untuk menurunkan morbiditas dan mortalitas kardiovaskular dan menghambat laju penyakit ginjal. Pada pasien hipertensi dapat dilakukan intervensi dengan modifikasi gaya hidup dan farmakologi. Modifikasi gaya hidup yang dapat dilakukan antara lain tidak merokok; pengaturan berat badan; kelebihan berat badan (BMI >25) merupakan faktor risiko serius terjadinya diabetes, penyakit jantung, arthritis, dan stroke, juga hipertensi, mengurangi asupan garam; aktivitas fisik yang cukup; disarankan untuk melakukan aerobic 3-4 kali dalam seminggu, dengan durasi setiap aerobic sekitar 40 menit; mengurangi minuman beralkohol. Intervensi farmakologi yang dapat 
diberikan antara lain diuretika, terutama yang jenis Thiazide atau AldosteroneAntagonist; Beta blocker; Calcium channel blocker atau calcium antagonist; Angiotensin Converting Enzyme Inhibitor; Angiotensin II receptor blocker atau AT, receptor antagonist/blocker. Masing- masing obat antihipertensi memiliki efektivitas dan keamanan dalam pengobatan hipertensi, tetapi dalam pemilihan obat hipertensi juga dipengaruhi beberapa faktor, yaitu faktor sosio-ekonomi, profil faktor risiko kardiovaskular, ada tidaknya kerusakan target organ, ada tidaknya pernyakit penyerta, variasi individu dari respon pasien terhadap obat antihipertensi, kemungkinan adanya interaksi dengan obat yang digunakan pasien untuk penyakit lainnya dan bukti ilmiah kemampuan obat anti hipertensi yang digunakan dalam menurunkan risiko kardiovaskular. ${ }^{4}$

\section{Kualitas Hidup}

Hunt (dalam Post, Witte, dan Schrijvers, 1999) mengemukakan bahwa "kalimat kualitas hidup" merupakan kalimat yang sulit untuk dioperasionalisasikan. Kualitas hidup dapat disamakan dengan keadaan kesehatan, fungsi fisik tubuh, perceived health status, kesehatan subjektif, persepsi mengenai kesehatan, simptom, kepuasan kebutuhan, kognisi individu, ketidakmampuan fungsional, gangguan psikiatri, kesejahteraan dan bahkan terkadang dapat bermakna lebih dari satu pada saat yang sama. Dimensi-dimensi dari kualitas hidup yang digunakan dalam penelitian ini mengacu pada dimensi-dimensi mengenai kualitas hidup yang terdapat dalam WHOQOL-BREF dimana terdapat enam dimensi yaitu (1) kesehatan fisik, (2) kesejahteraan psikologis, (3) tingkat kemandirian, (4) hubungan sosial, (5) hubungan dengan lingkungan, dan (6) keadaan spiritual. WHOQOL in kemudian dibuat lagi menjadi instrumen WHOQOL-BREF dimana enam dimensi tersebut kemudian dipersempit lagi menjadi empat dimensi yaitu (1) kesehatan fisik, (2) kesejahteraan psikologis, (3) hubungan sosial, dan (4) hubungan dengan lingkungan. Keempat dimensi ini kemudian dijabarkan menjadi beberapa faset sebagai berikut yaitu: ${ }^{7}$

a. Dimensi Kesehatan Fisik

- Aktifitas sehari-hari: menggambarkan kesulitan dan kemudahan yang dirasakan individu ketika melakukan kegiatan sehari-hari.

- Ketergantungan pada obat-obatan dan bantuan medis: menggambarkan seberapa besar kecenderungan individu dalam menggunakan obat-obatan atau bantuan medis lainnya dalam melakukan aktifitas sehari-hari.

- Energi dan kelelahan: menggambarkan tingkat kemampuan yang dimiliki oleh individu dalam menjalankan aktifvitasnya sehari-hari.
- Mobilitas: menggambarkan tingkat perpindahan yang mampu dilakukan oleh individu dengan mudah dan cepat.

- Sakit dan ketidaknyamanan: menggambarkan sejauh mana perasaan keresahan yang dirasakan individu terhadap hal-hal yang menyebabkan individu merasa sakit.

- Tidur dan istirahat: menggambarkan kualitas tidur dan istirahat yang dimiliki oleh individu.

- Kapasitas kerja: menggambarkan kemampuan yang dimiliki individu untuk menyelesaikan tugastugasnya.

\section{b. Dimensi Kesejahteraan Psikologis}

- Bodily image dan appearance: menggambarkan bagaiman individu memandang keadaan tubuh serta penampilannya.

- Perasaan negatif: menggambarkan adanya perasaan yang tidak menyenangkan yang dimiliki oleh individu.

- Perasaan positif: menggambarkan perasaan yang menyenangkan yang dimiliki oleh individu.

- Self-esteem:melihat bagaiman individu menilai atau menggambarkan dirinya sendiri.

- Berpikir, belajar, memori, dan konsentarsi: menggambarkan keadaan kognitif individu yang memungkinkan untuk berkonsentrasi.

c. Dimensi hubungan sosial

- Relasi personal: menggambarkan hubungan individu dengan orang lain.

- Dukungan sosial: menggambarkan adanya bantuan yang didapatkan oleh individu yang berasal dari lingkungan sekitarnya.

- Aktivitas seksual: menggambarkan kegiatan seksual yang dilakukan individu.

d. Dimensi hubungan dengan lingkungan.

- Sumber financial: menggambarkan keadaaan keuangan individu.

- Freedom, physical safety, dan, security: menggambarkan tingkat keamanan individu yang dapat mempengaruhi kebebasan dirinya.

- Perawatan kesehatan dan social care: ketersediaan layanan kesehatan dan perlindungan sosial

- Lingkungan rumah: menggambarkan keadaan tempat tinggal individu.

- Kesempatan untuk mendapatkan berbagai informasi baru dan keterampilan (skills): menggambarkan ada atau tidaknya kesempatan bagi individu untuk memperoleh hal-hal yang baru yang berguna bagi individu.

- Partisipasi dan kesempatan untuk melakukan rekreasi atau kegiatan yang menyenangkan: menggambarkan sejauh mana individu memiliki kesempatan dan dapat bergabung untuk berkreasi dan menikmati waktu luang. 
- Lingkungan fisik: menggambarkan keadaan lingkungan sekitar tempat tinggal individu (air, udara, iklim, polusi, dll)

- Transportasi: menggambarkan sarana kendaraan yang dapat dijangkau oleh individu.

\section{Hubungan Hipertensi Dengan Kualitas Hidup \\ Di samping implikasi terhadap organ,} hipertensi dapat memberikan pengaruh terhadap kehidupan sosial ekonomi dan kualitas hidup seseorang. Beberapa studi menyebutkan, individu dengan hipertensi memiliki skor yang lebih rendah di hampir semua dimensi yang diukur berdasarkan kuesioner WHOQOL dibandingkan dengan populasi. Hal ini disebabkan hipertensi memberikan pengaruh buruk terhadap vitalitas, fungsi sosial, kesehatan mental, dan fungsi psikologis. Pada beberapa studi lain menyebutkan, individu dengan hipertensi mengalami gejala-gejala seperti sakit kepala, depresi, cemas, dan mudah lelah yang mempengaruhi kualitas hidup seseorang pada berbagai dimensi. Oleh karena itu, dalam menangani individu dengan hipertensi sangat penting untuk mengukur kualitas hidup agar dapat dilakukan manajemen yang optimal. ${ }^{9}$

\section{METODE}

\section{A. Jenis Penelitian}

Jenis penelitian ini adalah deskriptif kuantitatif.

\section{B. Lokasi dan Waktu Penelitian}

Penelitian ini dilakukan di Posyandu lansia yang berada di wilayah kerja Puskesmas Rendang, Karangasem pada periode 27 Februari sampai 14 Maret 2015.

\section{Populasi dan Sampel}

Populasi target dalam penelitian ini adalah semua lansia di wilayah kerja Puskesmas Rendang. Populasi terjangkau dalam penelitian ini adalah semua lansia dengan hipertensi yang datang ke posyandu lansia wilayah kerja Puskesmas Rendang Karangasem. Sebagai sampel adalah lansia yang datang ke posyandu lansia wilayah kerja Puskesmas Rendang pada bulan Maret 2015 dipilih secara consecutive, bersedia ikut dalam penelitian, dan memenuhi kriteria inklusi. Kriteria inklusi adalah lansia diatas usia 60 tahun dan berdomisili di wilayah kerja Puskesmas Rendang. Kriteria eksklusi adalah responden menolak berpartisipasi dalam penelitian, menderita gangguan fungsi kognitif, menderita gangguan psikiatri berat dan sedang dalam perawatan psikiatri, memiliki cacat fisik (tuli, bisu, buta, lumpuh) dan tidak kooperatif.

\section{Pemilihan sampel}

\section{i) Besar sampe}

Besar sampel ditentukan berdasarkan rumus : $\mathrm{n}=\underline{\mathrm{Z} \alpha^{2} \mathrm{PQ}}$

\section{$d^{2}$}

Pada penghitungan sampel ini dikehendaki tingkat kepercayaan 95\% dan ketepatan absolut yang diinginkan sebesar $10 \%$. Proporsi lansia yang menderita hipertensi adalah 0,19 $Z \alpha=1,96, d=10 \%$ Jadi berdasarkan rumus diatas dapat dihitung $\mathrm{n}=\underline{\left(1,96^{2}\right) \times 0,19 \times(1-0,19)}=59$, dimana $\mathrm{Q}=(1-\mathrm{P})$

$$
(0,10)^{2}
$$

Karena jumlah populasi lansia di tempat penelitian kurang dari 10.000 orang, maka sampel untuk penelitian ini dikoreksi dengan cara sebagai berikut:

$$
\mathrm{nk}=\frac{\mathrm{n}}{1+\mathrm{n} / \mathrm{N}}=\frac{59}{1+59 / 5.435}=58,35
$$

Berdasarkan perhitungan diatas, jumlah sampel minimal dalam penelitian ini adalah sebanyak 58.

\section{ii) Teknik Pengambilan Sampel}

Posyandu lansia dipilih secara purposive sebagai tempat penelitian dengan mempertimbangkan jadwal pelaksaan kegiatan posyandu dengan keterbatasan waktu yang dimiliki oleh peneliti. Sampel dipilih dengan teknik consecutive sampling dari populasi terjangkau yang memenuhi kriteria inklusi tanpa ada kriteria eksklusi. Apabila ada sampel yang menolak atau tidak memenuhi kriteria, maka akan digantikan sampel lain yang dipilih secara consecutive sampling juga sampai jumlah sampel terpenuhi.

\section{Variabel Penelitian}

Antara variable yang didapatkan dalam penelitian ini adalah status hipertensi, derajat hipertensi, usia, status pernikahan, pekerjaan, riwayat penyakit lain dan kualitas hidup.

\section{E. Definisi Operasional Variabel i) Status hipertensi}

Yaitu subyek yang didapatkan tekanan darah sistolik $\geq$ $140 \mathrm{~mm} \mathrm{Hg}$ atau tekanan darah diastolik $\geq 90 \mathrm{mmHg}$ sesuai kriteria JNC 7. Pengukuran tekanan darah dilakukan dengan auskultasi dimana subyek dalam posisi duduk di atas bangku dengan telapak kaki menyentuh lantai dan istirahat 5 menit sebelum pemeriksaan. Subyek dianjurkan untuk tidak minum minuman yang mengandung kafein, merokok, dan olah raga minimal 30 menit sebelum pemeriksaan. Manset harus melingkari minimal $80 \%$ dari lingkar lengan atas. Pengukuran dilakukan dengan meraba terlebih dahulu arteri radialis subyek, kemudian alat dipompa 20-30 mm $\mathrm{Hg}$ di atas hilangnya denyutan arteri radialis. Tekanan manset kemudian diturunkan perlahan dengan kecepatan $2 \mathrm{mmHg} /$ detik. Tekanan darah sistolik adalah tekanan darah yang ditunjukkan tensimeter saat mulai terdengarnya suara korotkoff (onset fase 1) dan tekanan darah diastolik adalah saat menghilangnya suara korotkoff (onset fase 5).

\section{ii) Derajat Hipertensi}


Tabel 1. Klasifikasi Derajat Hipertensi menurut Joint National Committee 7 (JNC 7) ${ }^{2}$

\begin{tabular}{|l|c|c|c|}
\hline \multicolumn{1}{|c|}{ Kategori } & $\begin{array}{c}\text { Sistol } \\
(\mathrm{mmHg})\end{array}$ & dan/atau & $\begin{array}{c}\text { Diastole } \\
(\mathrm{mmHg})\end{array}$ \\
\hline Normal & $<120$ & Dan & $<80$ \\
\hline Pre hipertensi & $120-139$ & Atau & $80-89$ \\
\hline Hipertensi grade 1 & $140-159$ & Atau & $90-99$ \\
\hline Hipertensi grade 2 & $\geq 160$ & Atau & $\geq 100$ \\
\hline
\end{tabular}

\section{iii) Usia}

Usia individu penduduk lansia di posyandu lansia wilayah kerja Puskesmas Rendang tahun 2015 adalah berdasarkan KTP yang dikategorikan menurut cut-off point rerata dari usia lansia yang didapat saat pengumpulan data, sehingga pengelompokan usia menjadi dibawah rerata dan diatas rerata. Subjek yang dipilih merupakan subjek yang berusia $\geq 60$ tahun karena berdasarkan definisi WHO lansia adalah orang yang berusia $\geq 60$ tahun.

\section{iv) Status pernikahan}

Status pernikahan lansia wilayah kerja Puskesmas Rendang tahun 2015 berdasarkan wawancara, dibagi menjadi tidak menikah, menikah, janda, duda.

\section{v) Pekerjaan}

Pekerjaan individu penduduk lansia di posyandu lansia wilayah kerja Puskesmas Rendang tahun 2015, dikategorikan atas pensiunan/ tidak bekerja dan bekerja.

\section{vi) Riwayat penyakit lain}

Riwayat penyakit lain adalah penyakit sistemik kronis yang diderita oleh individu penduduk lansia di posyandu lansia wilayah kerja Puskesmas Rendang tahun 2015 yang sudah diderita selama 1 bulan.

\section{vii) Kualitas Hidup}

Kualitas hidup adalah persepsi individu mengenai posisi mereka dalam hidup dan hubungannya dengan tujuan, harapan, standar yang ditetapkan dan perhatian seseorang (WHOQOL Group dalam Lopez and Synder, 2004). Kualitas hidup diukur berdasarkan empat dimensi, yaitu :

- Dimensi Kesehatan Fisik : penilaian individu terhadap keadaan fisiknya seperti sakit, tidak nyaman, dll.

- Dimensi Kesejahteraan Psikologis : penilaian individu terhadap dirinya secara psikologis.

- Dimensi Hubungan Sosial : penilaian individu terhadap hubungannya dengan orang lain.

- Dimensi hubungan dengan lingkungan : penilaian individu terhadap hubungannya dengan lingkungan tempat tinggal, sarana, dan prasarana yang dimilikinya.

\section{F. Prosedur Pengumpulan Data \\ i) Instrumen Penelitian : Kuesioner, tensimeter dan stetoskop}

Alat ukur variabel kualitas hidup berupa kuesioner yang dibuat oleh WHO yaitu World Health Organization Quality Of Life - Bref (WHOQOL-BREF) yang merupakan pengembangan dari alat ukur WHOQOL-100. Alat ukur ini telah diadaptasi ke berbagai bahasa, termasuk bahasa Indonesia oleh Dr. Riza Sarasvita dan Dr. Satya Joewana untuk penelitian pada drug user (Wardhani, 2006). Wardhani (2006) juga melakukan uji psikometri terhadap alat ukur WHOQOL-BREF dan hasilnya adalah bahwa alat ukur ini adalah alat ukur yang valid dan reliable dalam mengukur kualitas hidup. Berikut ini adalah contoh item dari alat ukur WHOQOL-BREF dalam mengukur kualitas hidup.

Tabel 2. Contoh Item Alat Ukur WHOQOL-BREF

\begin{tabular}{|l|l|}
\hline Dimensi & Contoh Item Kuesioner WHOQOL-BREF \\
\hline $\begin{array}{l}\text { Kesehatan } \\
\text { Fisik }\end{array}$ & $\begin{array}{l}\text { Seberapa sering anda membutuhkan } \\
\text { bantuan medis untuk dapat berfungsi } \\
\text { dalam kehidupan sehari-hari? }\end{array}$ \\
\hline $\begin{array}{l}\text { Kesejahteraan } \\
\text { Psikologis }\end{array}$ & $\begin{array}{l}\text { Seberapa sering anda dapat menjalani } \\
\text { hidup anda sehari-hari dengan } \\
\text { perasaan gembira? }\end{array}$ \\
\hline $\begin{array}{l}\text { Hubungan } \\
\text { Sosial }\end{array}$ & $\begin{array}{l}\text { Seberapa puaskah anda dengan } \\
\text { dukungan yang anda peroleh dari } \\
\text { teman anda? }\end{array}$ \\
\hline $\begin{array}{l}\text { Hubungan } \\
\text { dengan } \\
\text { Lingkungan }\end{array}$ & $\begin{array}{l}\text { Seberapa puaskah anda dengan kondisi } \\
\text { tempat tinggal anda saat ini? }\end{array}$ \\
\hline
\end{tabular}

Untuk menjawab masing-masing pertanyaan, peserta diminta memilih satu angka dari skala 1 sampai 5 . WHOQOL-BREF hanya memberikan 1 macam skor yaitu skor dari tiap masing-masing dimensi yang menggambarkan respon masing-masing individu di tiap dimensi tersebut. Menurut Skevington (2008), alat ukur WHOQOL-BREF tidak memberikan skor menyeluruh yang merupakan gabungan dari tiap dimensi dan peneliti juga diperkenankan dalam mengubah skala dan cara perhitungannya. Skor tiap dimensi yang didapat dari alat ukur WHOQOL-BREF (raw score) harus ditransformasikan sehingga nilai skor dari alat ukur ini dapat dibandingkan dengan nilai skor yang digunakan dalam alat ukur WHOQOL-100 (WHO Groups, 2008). Skor tiap dimensi (raw score) ditransformasikan dalam skala 0-100 dengan menggunakan rumus baku yang sudah ditetapkan oleh WHO dibawah ini : 
Tabel 3. Penilaian Kualitas Hidup

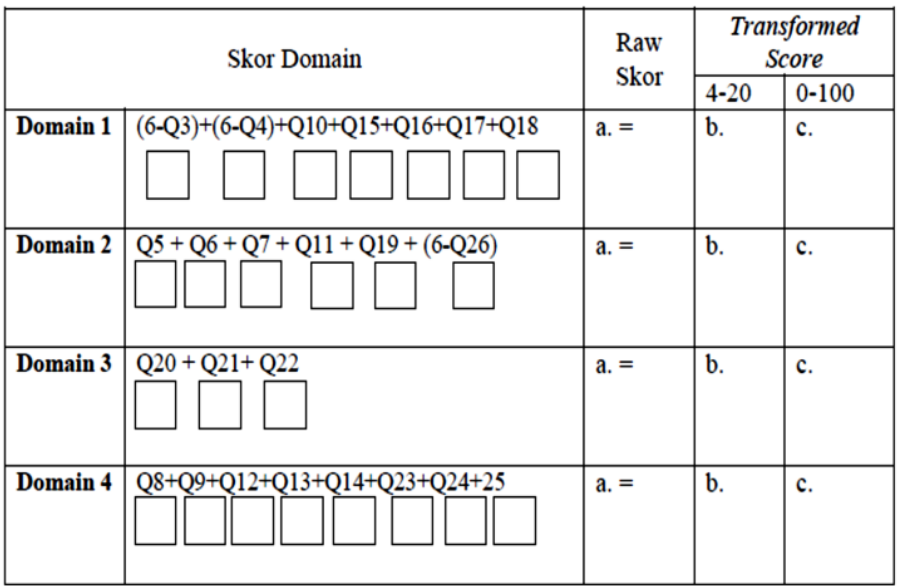

a. Raw Skor = penjumlahan nilai pada setiap pertanyaan dalam setiap domain

b. 4-20: Mean setiap domain $\times 4$

c. $0-100$ : [nilai (b)-4] $\times[100 / 16]$

\section{ii) Cara Pengumpulan Data}

Data primer merupakan data yang diperoleh langsung dari lansia dengan metode wawancara langsung yang dilakukan di posyandu lansia dengan menggunakan kuesioner. Data-data tersebut adalah data karakteristik lansia dan data mengenai kualitas hidup lansia.Data sekunder merupakan data yang diperoleh dari posyandu lansia berupa hasil pengukuran tekanan darah.

\section{G. Teknik Analisis Data}

Data dianalisis dengan menggunakan perangkat software komputer.

\section{HASIL}

\section{A. Karakteristik Responden}

Penelitian ini dilakukan terhadap 60 sampel penduduk lansia, yaitu penduduk berusia 60 tahun sampai dengan 90 tahun dan bertempat tinggal di Kecamatan Rendang, Kabupaten Karangasem. Dari sejumlah responden yang terpilih, seluruhnya menyatakan bersedia untuk ikut serta di dalam penelitian ini. Pengumpulan data dilaksanakan pada tanggal 27 Februari 2015- 15 Maret 2015. Dari 60 responden yang telah diwawancarai, diperoleh karakteristik penduduk meliputi usia, jenis kelamin, tingkat pendidikan, pekerjaan, status pernikahan dan riwayat penyakit kronis lainnya.

Tabel 4. Karakteristik Responden

\begin{tabular}{|c|l|c|c|}
\hline $\begin{array}{c}\mathrm{N} \\
\mathrm{O}\end{array}$ & Karakteristik & $\begin{array}{c}\text { Freku } \\
\text { ensi }\end{array}$ & $\begin{array}{c}\text { Persent } \\
\text { ase (\%) }\end{array}$ \\
\hline \multirow{2}{*}{1} & Kelompok Umur (Tahun) & & \\
& a. Dibawah Rerata & 32 & 53.3 \\
& b. Diaatas Rerata & 28 & 46.7 \\
\hline
\end{tabular}

\begin{tabular}{|c|c|c|c|}
\hline 2 & $\begin{array}{l}\text { Jenis Kelamin } \\
\begin{aligned} \text { a. } & \text { Laki-laki } \\
\text { b. } & \text { Perempuan }\end{aligned}\end{array}$ & $\begin{array}{l}32 \\
28 \\
\end{array}$ & $\begin{array}{l}53.3 \\
46.7 \\
\end{array}$ \\
\hline 3 & $\begin{array}{l}\text { Tingkat Pendidikan } \\
\begin{aligned} \text { a. } & \text { Tidak Sekolah } \\
\text { b. } & \text { SD } \\
\text { c. } & \text { SMP } \\
\text { d. } & \text { SMA } \\
\text { e. } & \text { Lainnya }\end{aligned}\end{array}$ & $\begin{array}{c}25 \\
31 \\
1 \\
2 \\
1\end{array}$ & $\begin{array}{c}41.7 \\
51.7 \\
1.7 \\
3.3 \\
1.7\end{array}$ \\
\hline 4 & $\begin{array}{l}\text { Pekerjaan } \\
\begin{aligned} \text { a. Ya } \\
\text { b. Tidak/Pensiunan }\end{aligned}\end{array}$ & $\begin{array}{l}41 \\
19\end{array}$ & $\begin{array}{l}68.3 \\
31.7\end{array}$ \\
\hline 5 & $\begin{array}{l}\text { Status Pernikahan (suami/istri } \\
\text { masih ada/tidak) } \\
\text { a. Ya } \\
\text { b. Tidak }\end{array}$ & $\begin{array}{l}43 \\
17\end{array}$ & $\begin{array}{l}71.7 \\
28.3\end{array}$ \\
\hline 6 & $\begin{array}{l}\text { Riwayat Penyakit Kronis } \\
\text { lainnya } \\
\text { a. Ya } \\
\text { b. Tidak }\end{array}$ & $\begin{array}{l}14 \\
46\end{array}$ & $\begin{array}{l}23.3 \\
76.7\end{array}$ \\
\hline \multicolumn{2}{|c|}{ Total } & 60 & 100 \\
\hline
\end{tabular}

Dari data yang diperoleh, mayoritas responden berada dalam kelompok umur 60 - 74 tahun yaitu masuk dalam katagori lanjut usia, sebesar $53.3 \%$ dari total responden. Usia rata-rata dari responden adalah 65.55. Sebagian besar responden berjenis kelamin laki-laki (32.0\%). Tingkat pendidikan dari lansia di posyandu wilayah kerja Puskesmas Rendang sebagian besar tamat SD yaitu (51.7\%). Para lansia yang bekerja di daerah ini sebanyak $41 \%$. Sebagian besar responden, tinggal dengan anggota keluarga mereka, dari 60 responden, $71.7 \%$ masih didampingi oleh pasangan hidup masing-masing, dan $28.3 \%$ suami atau istrinya telah meninggal.

\section{B. Distribusi Hipertensi}

Tabel 5. Distribusi Status Tensi

\begin{tabular}{|c|c|c|c|}
\hline $\begin{array}{c}\text { Status Tekanan } \\
\text { Darah }\end{array}$ & $\begin{array}{c}\text { Jumlah } \\
\text { Subyek }\end{array}$ & Jumlah & $\begin{array}{c}\text { Persentase } \\
(\%)\end{array}$ \\
\hline Hipertensi grade I & 60 & 26 & 43.3 \\
\hline Hipertensi grade II & 60 & 34 & 56.7 \\
\hline
\end{tabular}

Pada Tabel 5, tersaji status tekanan darah yang menunjukkan bahwa $43.3 \%$ berstatus hipertensi grade I dan $56.7 \%$ berstatus hipertensi grade II.

\section{C.Distribusi Kualitas Hidup Lansia}

Tabel 6. Distribusi Kualitas Hidup Lansia

\begin{tabular}{|c|l|l|l|}
\hline $\mathrm{N}$ & Karakteristik & $\begin{array}{l}\text { Freku } \\
\text { ensi }\end{array}$ & $\begin{array}{l}\text { Persent } \\
\text { ase (\%) }\end{array}$ \\
\hline 1 & Kualitas Hidup Lansia secara & & \\
\hline
\end{tabular}




\begin{tabular}{|c|c|c|c|}
\hline & $\begin{array}{c}\text { Umum } \\
\text { a. Baik } \\
\text { b. Buruk }\end{array}$ & 35 & 58.3 \\
\hline 2 & $\begin{array}{l}\text { Kualitas Hidup Lansia Dimensi } \\
\text { Kesehatan Fisik } \\
\text { a. Baik } \\
\text { b. Buruk }\end{array}$ & 17 & 28.7 \\
\hline 3 & 43 & 71.7 \\
& $\begin{array}{l}\text { Kualitas Hidup Lansia Dimensi } \\
\text { Psikologis } \\
\text { a. Baik } \\
\text { b. Buruk }\end{array}$ & 37 & 61.7 \\
\hline 4 & $\begin{array}{l}\text { Kualitas Hidup Lansia Dimensi } \\
\text { Personal Sosial } \\
\text { a. Baik } \\
\text { b. Buruk }\end{array}$ & 38.3 \\
\hline 5 & 30 & 50 \\
& $\begin{array}{l}\text { Kualitas Hidup Lansia Dimensi } \\
\text { Lingkungan } \\
\text { a. Baik } \\
\text { b. Buruk }\end{array}$ & 16 & 26.7 \\
\hline Total & 44 & 73.3 \\
\hline
\end{tabular}

Berdasarkan distribusi responden menurut kualitas hidupnya, didapatkan responden yang memiliki kualitas hidup baik sebanyak 35 orang (58.3\%) dan responden yang memiliki kualitas hidup buruk terdapat 25 orang (41.7\%). Responden lansia yang memilki kualitas hidup yang buruk berdasarkan kualitas kesehatan fisik lebih banyak dibandingkan dengan yang memiliki kualitas yang baik yaitu 43 orang $(71.7 \%)$. Kualitas hidup responden berdasarkan dimensi psikologis terdapat sebagian besar baik yaitu 37 orang $(61.7 \%)$. Responden yang memiliki kualitas hidup baik dan buruk sama jumlahnya berdasarkan dimensi personal sosial. Sedangkan Pada dimensi lingkungan, kualitas hidup yang buruk lebih banyak dibandingkan yang baik yaitu sebanyak 44 orang (73.3\%).

\section{Hasil Tabulasi Silang Variabel Karakteristik Subyek dengan Kualitas Hidup Lansia Secara Umum}

Tabel 7. Kualitas Hidup Lansia dengan Pekerjaan

\begin{tabular}{|l|l|l|l|}
\hline \multirow{2}{*}{$\begin{array}{l}\text { Variabel } \\
\text { Pekerjaan) }\end{array}$} & \multicolumn{2}{|l|}{$\begin{array}{l}\text { Kualitas } \\
\text { Lansia Secara Umum }\end{array}$} & $\begin{array}{l}\text { Total } \\
(\%)\end{array}$ \\
\cline { 2 - 3 } & Buruk (\%) & Baik (\%) & \multirow{2}{*}{100} \\
\hline $\begin{array}{l}\text { Tidak } \\
\text { bekerja/Pensiunan }\end{array}$ & $9(47.4)$ & $10(52.6)$ & \\
\hline Bekerja & $16(39.0)$ & 25(61.0) & 100 \\
\hline
\end{tabular}

Berdasarkan variabel pekerjaan, responden yang tidak bekerja atau pensiunan memiliki kualitas hidup yang buruk (47.4\%). Sedangkan responden yang bekerja memiliki kualitas hidup yang baik (61.0\%).

Tabel 8. Kualitas Hidup Lansia dengan Status Pernikahan

\begin{tabular}{|l|l|l|}
\hline Variabel & Kualitas Hidup Lansia & Total \\
\hline
\end{tabular}

\begin{tabular}{|l|l|l|l|}
\hline \multirow{2}{*}{$\begin{array}{l}\text { Status } \\
\text { Pernikahan) }\end{array}$} & \multicolumn{2}{|l|}{ Secara Umum } & $(\%)$ \\
\cline { 2 - 4 } & $\begin{array}{l}\text { Buruk } \\
(\%)\end{array}$ & Baik (\%) & \multirow{2}{*}{100} \\
\hline Menikah & $\begin{array}{l}15 \\
(34.9 .)\end{array}$ & $28(65.1)$ & \\
\hline Tidak Menikah & $10(58.8)$ & $7(41.2)$ & 100 \\
\hline
\end{tabular}

Berdasarkan variabel pasangan hidup, responden yang memiliki pasangan hidup, memiliki kualitas hidup yang buruk (34.9\%). Sedangkan responden yang tidak memiliki pasangan hidup, memiliki kualitas hidup yang buruk (58.8\%).

Tabel 9. Kualitas Hidup Lansia dengan Riwayat Penyakit Kronis Lain

\begin{tabular}{|l|l|l|l|}
\hline $\begin{array}{l}\text { Variabel (Riwayat } \\
\text { Penyakit Kronis) }\end{array}$ & \multicolumn{2}{|l|}{$\begin{array}{l}\text { Kualitas Hidup Lansia } \\
\text { Secara Umum }\end{array}$} & $\begin{array}{l}\text { Total } \\
(\%)\end{array}$ \\
\cline { 2 - 3 } & $\begin{array}{l}\text { Buruk } \\
(\%)\end{array}$ & Baik (\%) & \multirow{2}{*}{100} \\
\hline Ya & $4(28.6)$ & $10(71.4)$ & \\
\hline Tidak & $21(45.7)$ & $25(54.3)$ & 100 \\
\hline
\end{tabular}

Berdasarkan variabel riwayat penyakit kronis lainnya, responden yang memiliki riwayat penyakit kronis lain, memiliki kualitas hidup yang buruk (28.6\%). Sedangkan responden yang tidak memiliki riwayat penyakit kronis, memiliki kualitas hidup yang baik (54.3\%).

Tabel 10. Kualitas Hidup Lansia dengan Usia

\begin{tabular}{|c|l|l|l|}
\hline \multirow{2}{*}{$\begin{array}{c}\text { Variabel } \\
\text { (Usia) }\end{array}$} & \multicolumn{2}{|l|}{$\begin{array}{l}\text { Kualitas } \\
\text { LansiaSecara Umum }\end{array}$} & $\begin{array}{l}\text { Total } \\
(\%)\end{array}$ \\
\cline { 2 - 3 } & $\begin{array}{l}\text { Buruk } \\
(\%)\end{array}$ & Baik (\%) & \multirow{2}{*}{100} \\
\hline Diatas Rerata & $12(42.9)$ & $16(57.1)$ & 100 \\
\hline Dibawah Rerata & $13(40.6)$ & $19(59.4)$ & 100 \\
\hline
\end{tabular}

Berdasarkan variable usia didapatkan kelompok diatas rerata memiliki kualitas hidup yang buruk dengan presentase $42.9 \%$. Pada responden lansia dengan usia dibawah rerata memiliki kualitas hidup yang baik dengan presentase $59.4 \%$.

\begin{tabular}{|l|l|l|l|}
\hline \multirow{2}{*}{$\begin{array}{l}\text { Variabel (Jenis } \\
\text { Kelamin) }\end{array}$} & \multicolumn{2}{|l|}{$\begin{array}{l}\text { Kualitas Hidup Lansia } \\
\text { Secara Umum }\end{array}$} & $\begin{array}{l}\text { Total } \\
(\%)\end{array}$ \\
\cline { 2 - 3 } & Buruk(\%) & Baik (\%) & \multirow{2}{*}{100} \\
\hline Laki-Laki & $12(37.5)$ & $20(62.5)$ & 100 \\
\hline Perempuan & $13(46.4)$ & $15(53.6)$ & 100 \\
\hline
\end{tabular}

Tabel 11. Kualitas Hidup Lansia dengan Jenis Kelamin

Berdasarkan jenis kelamin, pada responden laki-laki didapatkan kualitas hidup yang baik dengan presentase $62.5 \%$. Sedangkan responden perempuan didapatkan kualitas hidup yang buruk dengan presentase $46.4 \%$.

Tabel 12. Kualitas Hidup Lansia dengan Tingkat Pendidikan 
Pada responden yang tidak bersekolah memiliki kualitas hidup yang buruk (28.0\%), responden dengan pendidikan SD memiliki kualitas hidup yang baik (48.4\%), responden dengan pendidikan SMP memiliki kualitas hidup buruk (100\%), responden dengan pendidikan SMA/Sederajat memiliki kualitas hidup baik $50 \%$ dan responden yang pendidikan lainnya yaitu Perguruan Tinggi memiliki kualitas buruk $0 \%$.

\section{PEMBAHASAN}

\section{A. Gambaran status tekanan darah lansia}

Dari hasil penelitian mengenai frekuensi distribusi hipertensi dengan menggunakan sampel penelitian masyarakat di wilayah kerja puskesmas Rendang, didapatkan kasus hipertensi grade । sebanyak 26 kasus(43.3\%) dan hipertensi grade II sebanyak 34 kasus(56.7\%) dengan total 60 sampel(100\%) penduduk usia lanjut di wilayah tersebut. Penelitian Dewhurst (2013) pada lansia di Tanzania, dimana didapatkan prevalensi hipertensi pada lansia cukup tinggi yaitu 69.9\% dari 2223 lansia. Stockslager (2008) menyebutkan bahwa insiden hipertensi meningkat seiring dengan bertambahnya usia. Hal ini juga sejalan dengan penelitian dimana hipertensi menempati $87 \%$ kasus pada orang yang berusia diatas 60 tahun. Manuel (2001) menyebutkan bahwa tekanan darah sistolik dan diastolik meningkat dengan bertambahnya usia.

National Health and Nutrition Examination Survey (NHANES) menyebutkan $65 \%$ orang diatas usia 65 tahun menderita hipertensi. Hipertensi pada lansia dimulai dengan atherosklerosis, gangguan struktur anatomi pembuluh darah perifer yang berlanjut dengan kekakuan pembuluh darah. Kekakuan pembuluh darah disertai dengan penyempitan dan kemungkinan pembesaran plague yang menghambat gangguan peredaran darah perifer.Kekakuan dan kelambanan alirandarah menyebabkan beban jantung bertambah berat yang akhirnya dekompensasi dengan peningkatan upaya pemompaan jantung yang memberikan gambaran peningkatan tekanan darah dalam sistem sirkulasi (Yogiantoro, 2009).

Adanya hipertensi merupakan faktor risiko morbiditas dan mortalitas untuk orang lanjut usia. Hipertensi masih merupakan faktor risiko utama untuk stroke, gagal jantung penyakit koroner, dimana peranannya diperkirakan lebih besar dibandingkan pada orang yang lebih muda. Lebih dari separuh kematian diatas usia 60 tahun disebabkan oleh penyakit jantung dan serebrovaskuler.

Pencegahan hipertensi dapat dilakukan dengan pencegahan, primer, sekunder, dan tersier. Pencegahan primer yaitu upaya awal pencegahan sebelum seseorang menderita hipertensi, dimana dilakukan penyuluhan faktor-faktor risiko hipertensi terutama pada kelompok risiko tinggi. Tujuan

\begin{tabular}{|l|l|l|l|}
\hline \multirow{2}{*}{$\begin{array}{l}\text { Variabel } \\
\text { (Tingkat }\end{array}$} & \multicolumn{2}{|l|}{$\begin{array}{l}\text { Kualitas Hidup Lansia } \\
\text { Pendidikan) }\end{array}$} & $\begin{array}{l}\text { Total } \\
\text { Secara Umum }\end{array}$ \\
\cline { 2 - 3 } & Buruk(\%) & Baik (\%) & \\
\hline Tidak Sekolah & $7(28.0)$ & $18(72.0)$ & 100 \\
\hline SD & $16(51.6)$ & $15(48.4)$ & 100 \\
\hline SMP & $1(100)$ & $0(.0)$ & 100 \\
\hline SMA /Sederajat & $1(50)$ & $1(50)$ & 100 \\
\hline Lainnya & $0(.0)$ & $1(100)$ & 100 \\
\hline
\end{tabular}

pencegahan primer adalah untuk mengurangi insidensi penyakit dengan cara mengendalikan penyebab-penyebab penyakit dan faktor-faktor risikonya. Pencegahan sekunder yaitu upaya pencegahan hipertensi yang sudah pernah terjadi untuk berulang atau menjadi berat. Pencegahan ini ditujukan untuk mengobati para penderita dan mengurangi akibat-akibat yang lebih serius dari penyakit, yaitu melalui diagnosis dini dan pemberian pengobatan. Dalam pencegahan ini dilakukan pemeriksaan tekanan darah secara teratur dan juga kepatuhan berobat bagi orang yang sudah pernah menderita hipertensi.Pencegahan tersier yaitu upaya mencegah terjadinya komplikasi yang lebih berat atau kematian. Upaya yang dilakukan pada pencegahan tersier ini yaitu menurunkan tekanan darah sampai batas aman dan mengobati penyakit yang dapat memperberat hipertensi. Pencegahan tersier dapat dilakukan dengan follow up penderita hipertensi yang mendapat terapi dan rehabilitasi. Follow up ditujukan untuk menentukan kemungkinan dilakukannya pengurangan atau penambahan dosis obat.

\section{B. Gambaran Kualitas Hidup Lansia}

Pada hakekatnya, gambaran kualitas hidup seseorang hanya dapat digambarkan oleh orang itu sendiri secara subjektif dan tidak dapat didefinisikan secara pasti (Cella, 1992). Hipertensi merupakan salah satu penyakit kronik yang disebabkan oleh multifaktorial dan berimplikasi ke banyak hal dalam kehidupan penderita. Di samping implikasi terhadap organ, hipertensi dapat memberikan pengaruh terhadap kehidupan sosial ekonomi dan kualitas hidup seseorang. Beberapa studi menyebutkan bahwa individu dengan hipertensi memiliki skor yang lebih rendah di hampir semua dimensi yang diukur berdasarkan kuesioner WHOQOL dibandingkan dengan populasi. Hal ini disebabkan karena hipertensi dapat memberikan pengaruh buruk terhadap vitalitas, fungsi sosial, kesehatan mental, dan fungsi psikologis. (Theodorou, Mamas et al, 2011). Sofiana (2011) menyimpulkan bahwa terdapat hubungan antara hipertensi dengan kualitas hidup yang menurun, disebutkan bahwa lansia dengan hipertensi 4.6 kali hidupnya kurang berkualitas dibandingkan dengan lansia yang tidak mengalami hipertensi.

Pada penelitian ini, ditinjau dari dimensi kesehatan fisik, lansia dengan hipertensi,ditemukan kualitas hidup yang buruk sebesar $71.7 \%$. Soni, et al (2010) dalam penelitiannya juga mengemukakan 
bahwa terdapat hubungan antara hipertensi dengan kualitas hidup yang rendah, terutama pada dimensi fisik dan psikologis. Stanley et al (2011) juga mendapatkan hasil dimana pada pasien hipertensi didapatkan kualitas hidup lebih buruk pada dimensi kesehatan fisik.

Tekanan darah tinggi atau hipertensi yang tidak terkontrol dan menyebabkan terjadi komplikasi yang dapat berujung pada terjadinya morbiditas dan mortalitas diduga menjadi salah satu mekanisme dari buruknya dimensi kesehatan fisik pada lansia dengan hipertensi. Pada beberapa studi lain menyebutkan, individu dengan hipertensi dilaporkan mengalami gejala-gejala seperti sakit kepala, depresi, cemas, dan mudah lelah. Gejala-gejala ini dilaporkan dapat mempengaruhi kualitas hidup seseorang pada berbagai dimensi terutama dimensi fisik. Oleh karena itu, dalam menangani individu dengan hipertensi sangat penting untuk mengukur kualitas hidup agar dapat dilakukan manajemen yang optimal. (Theodorou, Mamas et al, 2011)

Kualitas hidup yang buruk pada dimensi kesehatan fisik dapat dicegah dengan melakukan pencegahan primer, sekunder, dan tersier. Kualitas hidup kesehatan fisik yang baik dapat tercapai dan terpelihara jika pasien dapat mengontrol penyakitnya secara teratur. Dengan melakukan pengobatan yang rutin dan baik, gejala klinis dapat berkurang dan timbulnya komplikasi cenderung menurun. Pelaksanaan program dari puskesmas untuk meningkatkan kualitas hidup lansia di bidang kesehatan fisik juga dapat semakin digalakkan, seperti posyandu lansia, puskesmas keliling, senam lansia dan program lainnya yang dapat meningkatkan kualitas kesehatan para lansia.

Kualitas hidup jika ditinjau dari dimensi psikologisnya, responden lansia dengan hipertensi yang memiliki kualitas hidup yang buruk didapat sebanyak 38.3\%. Hasil penelitian yang didapat bertolak belakang dengan yang dipaparkan oleh Stanley et al (2011) yang mendapatkan hasil dimana pada pasien hipertensi kualitas hidup psikologisnya buruk, yaitu dengan presentase $67.8 \%$. Hal ini sesuai Begitu pula dengan penelitian Wang, et al (2009) di China yang menyebutkan bahwa hipertensi secara nyata mengganggu kualitas hidup, baik dari dimensi kesehatan fisik dan psikologis.

Adanya proses patologis akan mengakibatkan penurunan kemampuan fisik pada pasien hipertensi, yang dimanifestasikan dengan kelemahan, rasa tidak berenergi, pusing sehingga berdampak ke psikologis pasien dimana pasien merasa hidupnya tidak berarti akibat kelemahan dan proses penyakitnya yang merupakan penyakit terminal. Pasien dengan hipertensi juga harus mengkonsumsi obat seumur hidupnya untuk mencegah berbagai macam kompikasi yang dapat timbul. Hal ini memberikan dampak psikologis yang kurang baik terhadap pasien.

Namun hasil yang didapat pada penelitian ini masih mungkin terjadi, menurut Kartini dan Fitri(2014) mengemukakan bahwa orang dengan hipertensi yang memiliki optimisme dapat mengurangi perasaan dan pandangan negatif terhadap masalah menurut cara pandang yang lebih positif sehingga menimbulkan perasaan mampu menghadapi masalah kesehatan fisik dan psikis yang dialami untuk mencapai kualitas hidup yang lebih baik. Dan menurut penelitian yang dilakukan Riana(2014) adanya hubungan penyesuaian diri dengan kualitas hidup pada penderita hipertensi. Semakin baik penyesuaian diri maka akan semakin baik pula kualitas hidup yang dimiliki penderita hipertensi.

Kualitas hidup pada aspek personal sosial didapatkan hasil sebagai berikut, pada responden lansia dengan hipertensi, kualitas hidup dimensi personal sosial ditemukan kualitas hidup yang buruk sebesar 50.0\%. Menurut penelitian Sofiana (2009) yang menyebutkan bahwa pada pasien dengan hipertensi, peningkatan tekanan darah ke otak akan menyebabkan penurunan vaskularisasi di area otak yang mengakibatkan pasien sulit untuk berkonsentrasi, mudah marah, merasa tidak nyaman, dan berdampak pula pada aspek sosial dimana pasien tidak mau bersosialisasi karena merasakan kondisinya yang tidak nyaman. Hal ini menyebabkan penurunan kualitas hidup personal sosialnya. Pada studi yang dilakukan oleh Poljicanin, Tamara et al, juga menyebutkan bahwa individu dengan penyakit hipertensi dapat memberikan pengaruh yang buruk terhadap kualitas hidup individu tersebut. Pada individu dengan penyakit tersebut, terjadi penurunan kualitas hidup pada hampir seluruh dimensi yang diukur berdasarkan kuesioner WHO dimana yang paling terpengaruh adalah dimensi kesehatan fisik dan hubungan sosial. (Poljicanin, Tamara et al, 2010)

Pada penelitian ini, responden lansia dengan hipertensi yang memiliki gambaran kualitas hidup personal sosialnya baik memiliki angka yang sama dengan yang buruk yaitu $50,0 \%$, hal ini mungkin dapat disebabkan oleh tersedianya program puskesmas yang terlaksana dengan baik untuk lansia seperti posyandu lansia sehingga para lansia dapat saling berkumpul dan berkomunikasi dengan sesama lansia. Selain itu, banyaknya kegiatan adat di banjar dan tatanan rumah dari masyarakat adat Bali yang berdekatan antara sesama keluarga dan tetangga di daerah pedesaan memudahkan para lansia untuk bertemu dan saling bertukar pikiran. Kualitas hidup personal sosial dapat ditingkatkan dengan cara meningkatkan perhatian dari pasangan hidup, keluarga, caregiver, dan orang-orang disekitarnya. 
Pada responden lansia dengan hipertensi, kualitas hidup lansia dimensi lingkungan didapatkan baik sebesar $26.7 \%$. Dimensi lingkungan dapat dilihat dari dua aspek yaitu kebersihan tempat tinggal dan akses pelayanan kesehatan. Hal ini sangat disayangkan, karena melihat program puskesmas keliling telah berjalan sesuai dengan jadwal dan diharapkan dapat menjangkau semua lansia yang membutuhkan pelayanan kesehatan. Kemungkinan buruknya kualitas hidup lansia menurut dimensi lingkungan disebabkan dari sudut lingkungan tempat tinggal, kepuasan sampel terhadap kondisi tempat tinggal didapatkan masih kurang.

Kualitas lingkungan yang baik dapat didapatkan dari keadaan lingkungan pada lansia tergolong kurang baik. Hal ini mungkin dikarenakan sebagian besar dari lansia tinggal dengan anak ataupun keluarga besarnya, namun sibuk bekerja, ataupun tinggal sendiri, yang mengakibatkan kondisi tinggal yang kurang terpelihara. Mayoritas responden lansia bertempat tinggal cukup jauh dari sarana transportasi berupa kendaraan umum seperti bemo.

WHOQOL group (2004) dalam Murphy et al (2000), menyatakan kualitas hidup adalah persepsi individu terhadap posisinya dalam kehidupan, dalam konteks budaya dan sistem nilai dimana individu tersebut hidup, dan hubungan terhadap tujuan, harapan, standard dan keinginan. Hal ini merupakan suatu konsep yang dipadukan dengan berbagai cara seseorang untuk mendapat kesehatan fisik, keadaan psikologis, tingkat independen, hubungan sosial, dan hubungan dengan lingkungan disekitarnya. Jadi kualitas hidup memiliki hubungan yang saling berkaitan antar tiap dimensinya untuk membentuk kualitas hidup yang baik secara umum.

Pada penelitian ini, fokus perhatian pada pasien hipertensi dan didapatkan kualitas fisik dan lingkungan yang buruk. Kualitas fisik yang buruk dapat mempengaruhi kualitas kerja yang akan memberi pengaruh pada kemampuan untuk memenuhi kebutuhan sehari- hari. Berdasarkan segi kualitas lingkungan, penyakit yang diderita dapat menimbulkan beban finansial yang lebih apalagi jika lansia tidak memiliki jaminan kesehatan, hal ini akan menjadi beban dan secara tidak langsung mempengaruhi kemampuan lansia dalam pemenuhan kebutuhan yang lain. Kualitas lingkungan juga dipengaruhi oleh ketersediaan informasi, sarana kesehatan dan lingkungan rumah yang bersih dan memadai. Ketersediaan informasi dapat diperoleh dari penyuluhan yang sebaiknya diadakan secara rutin. Sarana kesehatan dan akses yang mudah untuk dijangkau membuat lansia dengan mudah untuk mengontrol penyakitnya sehingga secara tidak langsung mempengaruhi kualitas fisik dan psikologis.
Kualitas hidup lansia dapat ditingkatkan melalui beberapa program seperti posyandu lansia, puskesmas keliling, senam lansia, penyuluhan dan perlu diberikannya jaminan kesehatan kepada lansia. Dengan terpenuhinya segala aspek tersebut maka kualitas hidup lansia yang baik dapat diwujudkan.

\section{Kelemahan Penelitian}

- Pada penelitian ini, hanya diteliti mengenai gambaran status tekanan darah terhadap kualitas hidup lansia sehingga perlu diteliti mengenai faktor-faktor lain yang mempengaruhi kualitas hidup lansia seperti karakteristik subyek, adanya penyakit kronis lain, dan kepatuhan lansia hipertensi dalam minum obat dimana menurut penelitian lain hal tersebut sangat bermakna dalam menentukan kualitas hidup lansia.

- Beberapa definisi operasional variabel hanya didasarkan secara klinis dan wawancara tanpa pemeriksaan objektif.

- Jenis penelitian deskriptif kuantitatif tidak dapat mencari faktor yang bermakna mempengaruhi kualitas hidup lansia.

\section{SIMPULAN}

Dalam penelitian ini, kesimpulan yang didapat adalah

A. Jumlah responden terbanyak adalah lansia kelompok dibawah rerata (53.3\%), jenis kelamin laki-laki (53.3\%), tingkat pendidikan SD (51.7\%), bekerja (68.3\%), pendamping hidup (suami/istri) masih ada (71.7\%), dan mempunyai riwayat penyakit kronis selain hipertensi (23.3\%).

B. Kualitas hidup lansia secara umum baik (58.3\%), kualitas kesehatan fisik lansia buruk (71.7\%), kualitas psikologis baik (61.7\%), kualitas personal sosial tidak terlalu berpengaruh (50.0\%) dan kualitas lingkungan buruk (73.3\%).

\section{SARAN}

A. Sebagai masukan kepada Puskesmas Rendang untuk mematangkan kembali program bagi para lansia sehingga para lansia di wilayah kerja Puskesmas Rendang memiliki kualitas hidup yang baik terutama dari aspek kesehatan fisik dan lingkungan.

B. Kepada peneliti lain disarankan untuk melakukan penelitian lebih lanjut mengenai kualitas hidup pada lansia sehingga didapatkan faktor-faktor yang dapat mempengaruhi kualitas hidup lansia secara bermakna.

\section{DAFTAR PUSTAKA}

1. Angelats EG et.al. Hypertension, Hypertensive Crisis and Hypertensive Emergency: Approaches to Emergency Department Care, Emergencies 2010;22:209-19 
2. Chobaniam A.V, et al. Seventh Report of the Joint National Committee on Prevention, Detection, Evaluation, and Treatment of High Blood Pressure. (2003). JAMA 289 (19) : 2650

3. Depkes RI. (2011). Prevalensi Hipertensi di Indonesia. Diakses pada tanggal 23 Februari 2015, dari http://www.depkes.go.id

4. Jang et al.Association of early systolic blood pressure response to exercise with future cardiovascular events in patients with uncomplicated mild-to-moderate hypertension. 2005

5. Kemenkes RI. Buletin Jendela Data dan Informasi Penyakit Tidak Menular. Diakses pada tanggal 15 Februari 2015.

6. Mahmood, et.al. Prevalence and Epidemiological Correlates of Hypertension among Labour Population. National Journal of Community Medicine 2011 Volume 2 Issue 1

7. Power MJ. et.al. Quality of Life. Positive Pscychological Assessment: A Handbook of Models and Measures. Washingtin DC American Pschological Assosiation - WHOQOL Group. 2004.

8. Sugiharto, A. Faktor-faktor resiko hipertensi grade Il pada masyarakat - sebuah studi kasus di Kabupaten Karanganyar. 2008. Diakses pada tanggal 1 Maret 2015, dari http://eprints.undip.ac.id/16523/1/Aris_Sugiharto .pdf

9. Theodorou, Mamas et al. Quality of life measurement in patients with hypertension in Cyprus.Hellenic journal of cardiology : HJC = Hellēnikē kardiologikē epitheōrēsē, 2011; 52 (5) doi:None 2011 